\title{
Innovation and Practice of Art Design Professionals Cultivation in Higher Vocational Colleges from the Perspective of Great Country Craftsman
}

\author{
Xiaoxi $\mathrm{Hu}$ \\ Urban Vocational College of Sichuan \\ Sichuan, China
}

\begin{abstract}
The talent cultivation path of "base (skill) and project (teaching) and studio (specializing)" is proposed in combination with the demand of cultural and creative industry development for design professionals in higher vocational colleges and around the new cultivation objective of cultivating the higher vocational design professional talents with craftsman spirit. Cultivate students' design quality through "simulation plus genuine" practical environment, train the students' design skills through project teaching, cultivate students' craftsman spirit through master studio, and the talent cultivation principle of "work-study combination, school-enterprise cooperation, master lead, cultivating skills" has been practiced. In order to realize the talent cultivation effect, active exploration and practice shall be made for design specialty construction in higher vocational colleges in the aspects such as talent cultivation mode, "double-qualified teachers" construction, curriculum reform and resource construction, teaching method and means reform, practice teaching system and condition construction and the construction of ability for serving the society.
\end{abstract}

Keywords-higher vocational college; talent cultivation; specialty construction

\section{INTRODUCTION}

Based on the construction base at early stage, higher vocational specialty takes quality improvement as the core, promotes connotative development, and constantly strengthens the construction efforts from the aspects such as talent cultivation mode reform and innovation, "doublequalified teachers" construction, curriculum reform and resource construction, teaching method and means reform, practice teaching system and condition construction, management mechanism construction and the ability for serving the society, so as to form specialty construction effect. This paper proposes the talent cultivation principle of "work-study combination, school-enterprise cooperation, master lead, cultivating skills" in combination with the

Fund Project:

1. Project of Key Specialty Construction in Sichuan Higher Vocational Colleges in 2014, and it has been checked and accepted in 2017, Director: Xiaoxi $\mathrm{Hu}$;

2. Project of Innovative Development Plan for Sichuan Higher Vocational Education (2015-2018), project approval for key specialty construction (Project No.: XM1-40), Director: Xiaoxi Hu. practice of art design professionals cultivation in higher vocational colleges, and integrates the craftsman spirit cultivation into talent cultivation, so as to enhance the skills of design professionals and to better serve the demand of regional economic development.

\section{Propose the TAlent Cultivation PRinciple of "WORK-STUDY COMBINATION, SCHOOL-ENTERPRISE COOPERATION, MASTER LEAD, CULTIVATING SKILLS" IN COMBINATION WITH INDUSTRIAL DEVELOPMENT DEMAND AND CULTIVATION OBJECTIVE DIFFERENCE}

At present, the art design specialties such as art design, advertising design and making, environmental art design, costume design, furniture design, shoe pattern design and product modeling design are mainly opened in the higher vocational colleges nationwide. As for the cultivation objectives for professionals, such specialties in higher vocational colleges generally focus on the "designer", "craftsman" and other fields in art category. There is no obvious difference between the cultivation objectives for professionals proposed around the "designer" field and that of undergraduate art design specialties; the cultivation objectives for professionals proposed around "craftsman" field does not closely bound to the talent cultivation of higher education, making the ideas and modes for design professional cultivation different, moreover, the experimental training of professional equipment, the teaching facilities and equipment developed by the project are not the same. In addition, there exist the cross and confusion of talent cultivation objectives of art design specialty, for example, the overlap of the objectives between "designer" and "craftsman" will cause certain waste and duplicate construction in terms of professional teaching resources. As a result, the clear and accurate cultivation principle for art design talents is the guidance for specialty construction.

We hold the opinion that, the cultivation of core elements such as craftsman spirit, moral character shaping and crafts heritage shall be integrated actively into the art design professional cultivation in higher vocational colleges and integrate the cultivation of "craftsman spirit" into the new principle of talent cultivation against the uniqueness and long lasting feature of art design professional cultivation, and in 
combination with the changes in the demand of cultural and creative industry development for talents in the new period. Therefore, we proposed the talent cultivation principle of "work-study combination, school-enterprise cooperation, master lead, cultivating skills".

\section{INTEGRATE THE CULTIVATION OF “CRAFTSMAN SPIRIT" INTO THE NEW OBJECTIVES FOR TALENT Cultivation, AND ESTABlish THE TALENT Cultivation PATH OF "BASE (SKILL) AND PROJECT (TEACHING) AND STUDiO (SPECIALIZING)"}

We position the art design professional cultivation in higher vocational colleges at the cultivation of high-quality technical skilled talents who are familiar with the structure, understand the craftsmanship and can produce, which differs from the undergraduate college educated designer who is "unrestrained and is good at pure design with the design talent, focusing on modeling style and other art design or creative design", and distinguish from the general vocational college educated craftsman who is "proficient in craftsmanship, familiar with production, and can accurately express the modeling structure designer's design idea as the design samples".

To closely combine the cultivation of professional skills with the training of craftsman spirit, a new cultivation path is needed to be established. First, the professional skills of art design talents mainly consist of structure, craftsmanship and production, and on the basis of integrating the three aspects, the cultivation and formation of product innovation and design ability need a lot of design practice; second, the cultivation of craftsman spirit is the training of a higher level of professional identity and pride, which requires more refined and targeted personality cultivation on the basis of regular professional education; to achieve these goals, we establish the talent cultivation path of "base (skill) + project (teaching) + studio (specializing)" tightly around skills training, heritage of technology and art as well as the practice of craftsman mind. Guide the design representation and other professional basic ability against students' creative; carry out the project teaching through school-enterprise cooperation of "double-teacher for a course" and "multipleteacher for a course", to train students' application ability; cultivate students' product development and entrepreneurial ability in master studio, incubator base and other places. Recognize the systematic practice carrier of internship and post internship, create the simulation + genuine practice environment, establish the "teacher +technician + master" faculty team, and present the achievement of assignment work - product - commodity, so as to better serve the regional economic and social life.

\section{DRIVE THE ENTIRE ENHANCEMENT OF ART DESIGN SPECIALTIES WITH THE PROVINCIAL PROJECT OF KEY SPECIALTY CONSTRUCTION OF “ART DESIGN" AS THE LEAD}

The specialty of art design of Urban Vocational College of Sichuan was approved as Sichuan key specialty construction project in September 2014. Since then, it takes quality improvement as the core on the basis of original specialty construction, strengthens the construction efforts from the aspects such as management operation mechanism, faculty team, educational reform and scientific research, practical teaching and school-enterprise cooperation, completes the construction target and task, regulates the use of project budget, totally more than 5 million yuan, and ensures the orderly advancement of 134 acceptance points. Both construction task completion rate and capital utilization rate reach $100 \%$. The talent cultivation mode for art design specialty is constantly enriched and improved, as the cooperative enterprises are increased, order training is implemented, the practice and training sites inside and outside school are built, specialty construction committee is established, double-qualified teachers' team is constructed, internal training and external guide of specialty leader and core teachers are strengthened, project leader system is developed and implemented, quality resource sharing course reform and construction at college-level and provincial level is carried out, (smart) video studio and teaching resource platform are established, the reform and practice of teaching methods and means for professional core courses is performed, new paths of international exchange and cooperation are explored, and the industry-college-research results are improved.

\section{A. Construct the School-enterprise Cooperative Education Platform}

1) Deepen the construction of school-enterprise cooperative system and mechanism:

Practice the transformation of design specialty achievements "from assignment to work, from work to product, from product to commodity", implement modern apprenticeship cultivation relying on school-enterprise cooperation, thereby improving the professional cultivation mode. Establish one modern apprenticeship pilot project.

2) Establish specialty construction committee: Employ enterprise experts to establish specialty construction steering committee, hold the talent cultivation orientation, specifications and objectives, dual creative education and other seminars regularly and irregularly, introduce in enterprise experts and technical experts to participate in teaching, which has established effective promotion mechanism for student internship training, innovation and entrepreneurship cultivation.

3) Build the school-enterprise cooperative education center: Implement the project leader system in the specialty, and continuously promote and deepen project leader system in art design specialty project studio; take master studio as a platform, cultivate "craftsman spirit", and take initiative to explore the cultivation platform of "shop front and workshop rear". 6 project studios have been established including paper-rolling art and leather product, 3 master studios have been built including Peng Fei and Liu Guangkui, and more than 30 projects have been carried out, including design and production of household products and fashion art products as well as the landscape design of Meishan campus of the college. 


\section{B. Deepen Talent Cultivation Mode Reform}

1) Implement the order class cultivation: Continuously improve and implement talent cultivation mode, open enterprise innovative order class, to jointly develop the school-enterprise talent cultivation program, introduce the enterprise technician to school to teach and carry out the project, employ enterprise experts to give technical guidance and teaching guidance in school. After investigating the influential enterprises in the industry, build the "stimulation + genuine" practice teaching system and cultivate students" ability of design transformation "from assignment to work, from work to product, from product to commodity".

2) Enhance the core capability for employment and entrepreneurship: Strengthen the post ability cultivation with the center of students and the guidance of employment, thereby students are equipped with certain professional theory knowledge and strong professional practice ability, which highlights the core ability of frontline post of art design specialty and achieves "zero distance" employment. The graduate employment rate reaches $97 \%$ and above, and the employer's satisfaction rate is enhanced.

3) Promote teaching with competitions, so as to expand talent cultivation influence: In specialty construction, various competitions hold by the government, industry, business shall be performed for art design specialty, and the college shall set special fund guarantee system to ensure various projects are carried forward in an orderly fashion. Over the past three years, teachers and students have gained nearly 60 awards in multiple skill competitions hold by the government and industry, thereby the teacher's practice guiding ability and students' innovation and entrepreneurial ability is trained, and the social influence of this specialty is enhanced.

\section{Accelerate Curriculum and Teaching Resource Construction}

1) Create core curriculum, drive the curriculum and teaching resource construction: Construct curriculum with professional core course as the key object, build the gradient construction of quality resource sharing class at school level, teaching reform class at school level and quality resource sharing course at provincial level, and improve relevant teaching resource construction. In 2014 and 2015, 2 quality resource sharing courses at provincial level were approved for art design specialty; in addition, 1 quality resource sharing course at provincial level and 1 innovation and entrepreneurship education demonstration course for costume specialty are promoted.

2) Implement online and offline teaching sharing using information platform: Employ the teaching mode of "driven by task and guided by project", practice the reform of professional core curriculum teaching method and means, carry forward the construction of smart classroom and video room in terms of facilities, use the Learning Through and other information platform in terms of software to make micro-lesson, online class and other teaching video resources, so as to promote teachers to get effectiveness in the aspects such as information-based teaching design, information-based classroom teaching and practice teaching. Through the practice of information-based teaching means, teachers gained the third prize in information-based classroom teaching competition of Sichuan higher vocational colleges in 2014 and 2015, and received the third prized of Sichuan Province in national college (vocational college) micro-class teaching in 2015.

\section{Strengthen Internal Training and External Guidance, and Create "Double Qualified" Teaching Staff}

1) Intensify team construction, implement classified cultivation: Strengthen the specialty leader's international vision cultivation through participating in international cooperation and exchange; reinforce the cultivation of key teachers' teaching and professional skills by way of surveying, subject-based learning and enterprise practice and exercise; promote the growth of young teachers and enrich the full-time faculty via the experienced teachers leading new teachers, one-on-one assistance and other ways. A total of 11 teachers were sent to participate in production practice and exercise over the past three years, and more than 40 teachers are organized to participate in national training, provincial training and various skill training.

2) Cultivate the double qualified teachers to enhance the team's ability: Carry out the "double qualified" teachers cultivation through participating in production practice and exercise, skill training, involving in exhibition and competition and other ways, to improve the proportion of double qualified teachers among the professional teachers.

3) Introduce in masters to cultivate craftsman spirit: Employ the masters who are proficient in skills from famous design company and independent designer studio by way of visiting, employment and absorption, to improve master employment and management mechanism and promote the cultivation of students' craftsman spirit. 5 . Strengthen practice education to realize the transformation from assignment to product

- Improve the information capability of practice teaching and the training conditions. Conduct "digital and information-based" design training room construction together with the enterprises that cooperate with school, so as to enhance students' ability of design representation using multimedia information technology means.

- Build the "process and model production" training room to strengthen technical skills. Construct the training room for "creative expression" and "model making", which are suitable for the training of wood carving, Sichuan embroidery, pottery, and lacquer craft production of multiple orientation including art design, environmental art design and home design. 
- Collect various resources to create master studio. Introduce in the masters at provincial level who are proficient in arts and crafts, industrial design and product design to strengthen achievement transformation and improve the ability of serving the society. Facilities were supplemented and the design and production of folk traditional crafts were expanded since 2014 based on Pengfei Art Studio, and the "Muyushi" Studio was established to undertake leather accessories, sculpture making and other projects; in 2015, Li Xianhai, Sichuan art master, was invited to school to create wood carving studio, thereby cultivating students' craftsman spirit; in 2016, constructed "Sichuan Embroidery" nonheritage culture studio together with Chengdu Xiulandao Investment Management Co., Ltd.; in 2016, constructed creative product studio jointly with enterprise expert Liu Guangkui, focusing on product design and playing the role of leading in technical innovation.

\section{E. Strengthen Achievement Transformation and Improve the Ability of Serving the Society}

1) Improve professional service and focus on the transformation of scientific research achievements: In order to improve professional skills and the ability of serving the society, the teacher leads students to develop Sichuan embroidery products for more than ten enterprises, which products include more than thirty items, such as creative furniture design, wall painting, embossed products and cultural and creative products, gaining the economic benefit of nearly 400,000 yuan.

2) Support regional economic development relying on specialty construction: Professional teachers contribute ideas and exert efforts for local construction and development actively, reflecting the ability of higher vocational colleges to serve regional society and economic development. In recent years, multiple suggestions about "Protection and Planning of Urban Ecosystem in Urban Planning" have been proposed for the government of Meishan City and have been adopted.

\section{CONCLUSION}

Regard the key specialty construction as the lead to drive the whole enhancement of art design specialties, and explore the education principle of "one-center five-integration" through all-round construction; practice the talent cultivation mode of work-study combination, school-enterprise cooperation, master lead and cultivating skills of "base + project + studio" of this specialty in depth via teaching platform construction; carry out the talent cultivation principle of "from assignment to work, from work to product, from product to commodity" further by way of teaching method reform. Art design specialty adheres to the road of industry-school-research in the process of construction, builds the "double qualified teachers + masters" team to cultivate students' professional ability, realizes joint review of program, co-cultivation of talents, joint construction of teaching staff, common use of environment, joint research of project and achievement sharing, relying on the "stimulation + genuine" practice teaching platform inside campus and the carrier of "understanding practice, in-class practice, project training, social practice and post-practice", with the specialty construction having gained obvious achievements.

\section{REFERENCES}

[1] Si Yuanlei. Research on Brand Specialty Construction in Higher Vocational Colleges --- taking School of Information and Art, Jiangsu Vocational Institute of Architectural Technology as an Example [J], Journal of Hebei Software Institute, 2017 (9): 26-28.

[2] Tong Weijun, Ren Zhanying. On the Actual Difficulties of Industry and Enterprise to Open Vocational Colleges and the Countermeasures [J], Research in Higher Education of Engineering, 2015 (6): 167-172.

[3] Ministry of Education. Notice of the Ministry of Education on Issuing the Action Plan of for Innovative Development of Higher Vocational Education (2015-2018) [Z], Jiaozhicheng No. [2015]9.

[4] Mao Jiaoyan, Chen Xuezhong. Study on Integration Model of Entrepreneurship Education and Vocational Skill Education in Higher Vocational Colleges [J]. Success (Education Edition), 2013 (3) : 102 103.

[5] Xing Difeng. Path Selection of Innovation and Entrepreneurship Education in Higher Vocational Colleges [J]. Heilongjiang Researches on Higher Education, 2011 (4): 86-88.

[6] Yang Yong, Yuan Pei, Feng Zhenye. Exploration on College Campus Environment Construction for Innovative Talents Cultivation [J]. Journal of Dalian University, 2013 (12): 118-123. 